\title{
Major Determinants of Female Child Labour in Urban Multan (Punjab-Pakistan)
}

\author{
Karamat Ali and Abdul Hamid*
}

\begin{abstract}
In recent years, the sensitive issue of child labour has received world-wide attention and has become the focus of serious discussion in developing as well as developed countries. Any exact information on child labour is usually hard to come by as most of the children work in the unorganised informal sector, which is neither regulated by labour laws nor is monitored by any organisation. These working children are usually illiterate and start working at a very early age, are inexperienced and vulnerable, they usually work long hours in deplorable conditions, have no medical cover, go without sufficient and proper food and clothing, and get little rest and recreation. In this paper, an attempt has been made to analyse the major causes of female child labour in the city of Multan and certain measures and policies have been suggested which could help in bringing an end to this inhumane practice. Legislation against child labour is not an ideal solution in a country such as Pakistan. The child labour phenomena is not as simple as it appears and needs consideration in the context of the microeconomics of the family and population growth and macroeconomics of the social security structure of a country, unemployment, underemployment, opportunity cost and productivity of formal education. There are very few studies on child labour in Pakistan and on female child labour, hardly any study can be found. Data has been collected for 60 female child labourers, employed as maidservants, baby sitters and other household activities etc. Most of these female children work in the houses of educated and well off people who are usually against child labour. This exploitation of child labour cannot be stopped by child labour laws only. In this regard, other measures such as more facilities for education and vocational training are indispensable. A group of social volunteers comprising workers, employers, government officers, media experts, members of non-government organisations and educationists should make earnest and sincere efforts to achieve the objective of minimising child labour and improve their living conditions as much as possible.
\end{abstract}

\footnotetext{
* The authors are Professor and Lecturer in the Department of Economics, Bahauddin Zakariya University, Multan, respectively.
} 


\section{Introduction}

Child labour is one of the serious issues which has been widely discussed recently and is still being discussed in developing as well as in developed countries. Child labour may be defined as full time employment of a person under the age of 16 at a wage rate lower than the existing wage rate in the labour market. Innocent little children, who should be at schools or at play grounds, are on the path of earning their own and their families' livings. Taking advantage of their economic compulsions, the employers hire children, pay them less than what they pay adult workers doing the same job, and they are thus exploited. Most of the children who work are usually employed in the informal sector which is not regulated by labour laws or any organisation. These working children are usually illiterate and start working at a very early age. Lacking education, these children have to work for long hours and they are deprived of even the basic needs such as food, clothing, health facilities and rest or recreation. The majority of them suffer from various respiratory diseases, tuberculosis, anemia, sight blindness, cancer and malnutrition, etc.

Child labour exists all over the world. To collect reliable data about it is very difficult as most of the children work in the unorganised informal sector. According to an International Labour Organisation (ILO) report (1994) about 150 million children between 6 and 14 years work all over the world ${ }^{1}$. According to another ILO report (1993) on the average 18 per cent of the total number of children in the world are engaged in child labour. Their region wise break up is 7 per cent working in Latin America, 18 per cent in Asia and 25 per cent in Africa ${ }^{2}$. A report entitled "The State of Working America 1992-93" stated that nearly 5.5 million children work in the U.S. Some 676,000 children work in the underground economy over which the government has little or no control. In 1990 job related deaths and casualties among these children numbered 139 and 71,660 respectively ${ }^{3}$.

The child labour problem is more serious in developing countries and especially in Pakistan. According to the 1981 Census, the child population (5-14) in Pakistan is about 30 per cent of the total population, of which 40 per cent consists of child labour ${ }^{4}$. The ILO report (1990) mentioned some very disturbing facts relating to the carpet weaving child

\footnotetext{
1 "Why do children work?" Young World, The Daily Dawn Karachi, June 30, 1994.

${ }^{2}$ The Daily Dawn Karachi, April 22, 1993.

3 "Child Labour in America": The Daily Dawn Karachi, September 19, 1992.

${ }^{4}$ Statistical Pocket Book of Pakistan, 1991: Statistics Divisions, Government of Pakistan, March, 1991.
} 
labour of Pakistan. According to the report, half of the 50,000 bonded children in the carpet industries died before reaching the age of $12^{5}$.

Legislation against child labour is not an ideal solution in a country such as Pakistan. The child labour phenomena is not as simple as it appears and needs consideration in the context of the microeconomics of family and population growth and macroeconomics of the social security structure of a country, unemployment, underemployment, opportunity cost and productivity of formal education.

In this paper an attempt has been made to analyse the major causes of female child labour in the city of Multan and certain measures and policies have been suggested to hamper this inhumane practice. The layout of the study is as follows: literature of child labour has been reviewed in section II, section III consists of methodology, data description and hypothesis. Results and findings based on the survey ${ }^{6}$ conducted in Multan city have been discussed in section IV and finally, policy implications and conclusions are presented in section $\mathrm{V}$.

\section{Review of Literature}

Child labour has been a problem in both developing and developed countries. According to an ILO report (1993), child labour is 18 per cent of all the children in the world ${ }^{2}$. The problem is more serious in developing countries which suffer from over population, unemployment, illiteracy and wide spread poverty. These are the major causes of child labour. According to BBC television, over 55 million children work in India ${ }^{7}$.

M. Weiner and Omar Noman (1994) analysed child labour and education policies in India and Pakistan. According to their analysis, India and Pakistan have fallen behind the rest of Asian countries due to their wrong policies and not because of their poverty. There is widespread illiteracy and child labour in these countries. Education, especially in Pakistan, has secondary importance. It remains near the bottom among the countries of the world in respect of social indicators of development. Amongst 150 nations, Pakistan ranks 130th as regards the proportion of children attending school to the children of school going age, 120 in literacy rate, and 118 in per capita expenditure on health. In other words, there is a wide gulf between Pakistan's economic growth and social development performance. Half of Pakistan's children between ages 5 and

\footnotetext{
${ }^{5}$ For further detail see the Daily Dawn Karachi "Without Child Labour", June, 1990.

${ }^{6}$ Survey conducted by Dr. Karamat Ali, et.al. for the female child labour in Multan city, for the year 1993.

${ }^{7}$ BBC, World Business News, Telecast on April 1, 1994 at 13.25 hours GMT.
} 
9 do not attend school. In rural areas only 17 per cent of girls and 43 per cent of boys complete five years of education. The overall primary and secondary enrollment rate is only 29 per cent. According to the 1981 Census, instead of attending schools, most of the children join the labour force and work in fields and in thousands of small workshops producing all types of goods including garments, carpets, sporting goods, leather goods, footwear, etc.

Pakistan's labour participation rate for male children is higher than many other developing countries which are at the same level of development. According to the 1981 Census, 35 per cent of male children in the 10 to 14 years age group worked. This implies that the total volume of male child labour in Pakistan is over 10 million. This figure is four times the size of Singapore's total population, twice that of Norway's and equal to the entire Greek population. As far as female child labour is concerned, most of them are confined to domestic help and in household enterprises. So accurate data about female child labour is hardly available. However, according to a 1981 Census estimation, the female child labour participation rate is about 5 per cent.

According to M. Weiner, and Omar Noman (1994), about 82 million children in India did not attend schools. That many of these children were engaged in labour, was difficult to find out because a large number of them were doing unpaid work in fields or in cottage industries, beside their parents and were not reported in the Census. A large number of children work in cottage industries, producing carpets, matches, firecrackers, brasswear, hand loomed clothes, baskets, bangles and other traditional handicrafts. Given the uncertainties, it is no wonder that estimates of child labour vary so greatly in India. According to the 1981 Census of India, 13.6 million children were at work, of which 8.1 million were male and 5.5 million female. Of these, 11.6 million were in agricultural work. Other studies showed the number of child workers higher. According to the Official National Sample Survey of 1983, child labourers were 17.4 million.

Weiner suggested four themes in his study to solve the child labour problem. According to his study, the adoption of a compulsory primary education policy was often an established practice in all the developed nations before they began rapid economic growth. Second, the establishment of compulsory education was essential for the elimination of child labour. In the absence of universal and compulsory schooling, children enter the labour force at the behest of their parents. It is easier to force parents to send their children to schools than to force employers not to hire children. Thirdly, people should be made aware of the importance of 
education and skills. An educated worker should be given more incentives and wages. People should know that child labour is not simply the result of poverty, it is also one of its principal causes. The fourth theme is that in all economically developed and rapidly growing countries, education is not regarded merely as a right, but as an obligation. No matter how poor the children may be, governments believe that employers should not employ children and parents should see to it that their children do not leave school before completing their studies. So governments should provide adequate facilities for schooling even in remote areas.

Akmal Hussain (1988), conducted a survey on child labour in Lahore and estimated that about 14 million children between 5 to 15 years of age work in Pakistan.

A report on the "Situation of Child Labour in Pakistan" $(1998)^{8}$ suggested that 23 per cent of the rural children work, while in cities only 10 per cent children are at work. The report found that these child labourers work for long hours without any rest and proper food. Their wages are very low and they are badly exploited, especially child labour in the carpet industry who are more vulnerable and miserable.

Akmal Hussain (1988) analysed the relationship between poverty and child labour. According to the study, about 40,000 children die everyday due to malnutrition in poor developing countries. He found out that children work for longer hours, than is the usual practice for other labour, i.e. 54 to 72 hours in a week for a pittance of US \$ 5 per month. According to his findings poverty is the major cause of malnutrition and child labour in developing countries.

Raja Chand (1983) studied 50 children in various auto workshops and found that 72 per cent of the children who left schools did so either due to poverty, or lack of interest or teacher's harsh attitude. Most of them work for 9 to 10 hours a day and belong to illiterate families.

A UNICEF report (1990) on child labour in the carpet weaving industry in Punjab found that more than 80 per cent of carpet weavers in Punjab were children below the age of 15 . The majority of them have to work about 10 to 12 hours a day at a wage of Rs. 200/- to 500/- per month. Most of them suffer from fatal diseases as working conditions and the atmosphere are very poor. Half of them never went to school and the rest have dropped out due to their disinterest in studies.

\footnotetext{
${ }^{8}$ Convention on the Rights of the Child, Islamabad, UNICEF Publication, Printed at Pictorial Printers, Islamabad, (1990).
} 
Shaheen Khan (1982) conducted a survey of 100 children working in different trades in Lahore, Gujranwala and Sialkot and found that the major causes of child labour were poverty, family tradition, fight for survival, disillusionment with schooling and lack of any other choice. She found that the average age of these working children was 11 years and they had to provide for their families' day-to-day needs.

Another study done by Sabeeha Hafeez (1988) for Karachi and villages near Karachi found two main causes of child labour-first, poverty and second, parental authority. These children usually belong to very poor and illiterate families. The life expectancy is very low for the adult members of these families and they consider children a major source of their income. They compel their children to work. Referring to the problem of child labour in villages, she says that children are not only exploited by parents but parents have full control over the destiny of their children. Referring to education as an alternative to work, she says that for this parents have to be convinced that education can deliver good opportunities for them and for their children.

Sabeeha Hafeez (1979) made an analysis of child labour in a village of Sindh and found that most of the children who had to share their father's work did not go to school due to work, poverty in their families, and lack of educational facilities. As regards girls, 53.7 per cent of those above the age of 5 when not attending school were found engaged in household chores. The girls are confined by the restraints and demands of the role their society expects them to play. They cannot exceed the prescribed limits outlined by their society. A girl who willingly takes upon herself the burden of household chores and tries her best to unburden her mother is considered to be a loving and virtuous daughter. The regular increase in the number of children in a family entails additional work for elder children, especially for the girls.

M. Anwar and M. Naeem (1986) analysed the child labour situation in rural Punjab and found that working conditions were inimical for children. Most of them do not go to school and suffer malnutrition, poor health and fatal diseases. The children have to perform inadequate services to meet their and their families' basic needs.

From the literature review it is clear that there are very few studies on child labour in Pakistan and on female child labour, scarcely any study can be found. We have attempted to carry out a study of the major determinants of female child labour in Multan city and to propose such measures and policies which in our view could prove effective, relevant and fruitful throughout the country. 


\section{Hypothesis, Methodology and Data Description}

There has been a rapid increase in male as well female child labour. An analysis of major causes of female child labour in Multan city is undertaken. The following may be the major determinants of female child labour.

- Poverty: Most of the child labourers belong to poor families.

- Parents' Education: Parents of female child labour are usually illiterate and unskilled.

- Family Tradition: Father works as blue-collar worker while mother as labourer in others peoples' houses.

- Family Size: $\quad$ Family size of female child labour is large.

- Increased Educational Expenditure and limited schooling facilities.

- $\quad$ Low Wage Rates of female child labour.

Another hypothesis is that educated and rich businessmen who usually profess to be against child labour are the major employers of children (very profitable owing to nominal wages paid to children and their long working hours).

In the specification form, the above causes may be written as:

$$
\mathrm{CL}=\mathrm{f}[\mathrm{P}, \mathrm{PE}, \mathrm{FT}, \mathrm{FS}, \mathrm{EE}, \mathrm{W}]+\mathrm{ei}
$$

Where $C L=$ supply of female child labour.

$$
\begin{array}{lll}
\mathrm{P} & = & \text { Poverty (measured by family's income) } \\
\mathrm{PE} & =\text { Parents' Education. } \\
\mathrm{FT} & = & \text { Family Tradition. } \\
\mathrm{FS} & = & \text { Family Size. } \\
\mathrm{EE} & = & \text { Educational Expenditure. } \\
\mathrm{W} & = & \text { Wages of adult labour. } \\
\mathrm{Ei} & = & \text { Error term. }
\end{array}
$$


Data has been collected for a random sample of 60 for female children in Multan city doing household chores i.e. cleaning, washing ironing, cooking, child care, etc. as paid maid servants in other people's houses of middle class families. The survey includes details about their daily routines, monthly income, family income, parents' education, working conditions, family size, number of working hours for the year 1993. A discussion of survey results is presented in Section-IV.

\section{Discussion of Results and Findings}

Poverty breeds scarcity and misery. One of the important determinants of female child labour is family's poor economic conditions. Children, whether they are male or female, have to work to fulfill their families' day-to-day needs. The hypothesis that poverty and low family income is a major cause of female child labour is supported by survey results given in Tables-1 and 2. Table-1 gives the data on the income of the father.

Table-1: Distribution of Female Child Labour According to the Monthly Income of Father

\begin{tabular}{clcc}
\hline No. & Monthly Income (Rs.) & Frequency & Percentage \\
\hline 1. & $100-400$ & 05 & 08.34 \\
2. & $500-1000$ & 28 & 46.67 \\
3. & $1100-1500$ & 04 & 06.67 \\
4. & $1600-2000$ & 06 & 10.00 \\
5. & $2100-2500$ & -- & -- \\
6. & $2600-3000$ & 02 & 03.34 \\
7. & 6000 & 01 & 01.67 \\
8. & 4 mon wheat & 01 & 01.67 \\
9. & Casual labour & 01 & 01.67 \\
10. & Nothing & 12 & 20.00 \\
\hline Total & ---- & 60 & 100.00 \\
\hline
\end{tabular}

A large proportion (55.01 per cent) of the fathers of female child workers earn Rs. 1000/- or less per month. The income of the fathers of 20 per cent of the surveyed female child labour is nil. 
Table-2: Distribution of Female Child Labour According to the Monthly Income of Mother

\begin{tabular}{clcc}
\hline No. & Monthly Income (Rs.) & Frequency & Percentage \\
\hline 1. & $100-200$ & 08 & 13.34 \\
2. & $300-400$ & 07 & 11.67 \\
3. & $500-600$ & 08 & 13.34 \\
4. & $700-800$ & 05 & 08.34 \\
5. & $900-1000$ & 03 & 05.00 \\
6. & Monthly Ration & 01 & 01.67 \\
7. & Nothing & 27 & 45.00 \\
8. & Death & 01 & 01.67 \\
\hline Total & ---- & 60 & 100.00 \\
\hline
\end{tabular}

Table-2 provides information about female child 1abourers' mothers' monthly income. This distribution follows the same pattern given in Table1. Forty five percent of the total female child labourers' mothers' monthly income is zero. About 95 per cent female child labour is such whose mothers have monthly income of Rs. $1,000 /-$ or less. That is the very reason why children in such families are compelled to work with their parents to provide food, clothing, housing and other basic needs to their large sized families. Children are considered a major source of income and are kept away from schooling (especially female children).

Uneducated or poorly educated parents are another cause of female child labour. There is an inverse relationship between parents' education and the supply of female child labour. Educated parents are aware of the worth of educating their children. Illiterate parents consider that sending their children to school is very costly and just a wastage of money and time as they take into account the running cost and opportunity cost of educating their children, and especially female children. Fear of unemployment also discourages them from sending their children to school or keeping them there to complete their education. The fact that a large number of educated young people fail to find any employment, reinforces this fear of unemployment. Survey data shows that parents of most of female child labourers were illiterate or very poorly educated. Tables-3 and 4 provide information about parents' education leve1. 
Table-3: Distribution of Female Child Labour According to Education of Father

\begin{tabular}{clcc}
\hline No. & Father's Education & Frequency & Percentage \\
\hline 1. & Illiterate & 51 & 85.00 \\
2. & Primary & 08 & 13.33 \\
3. & Matric & 01 & 01.67 \\
\hline Total & ---- & 60 & 100.00 \\
\hline
\end{tabular}

Table-4: Distribution of Female Child Labour According to Educational Level of Mother

\begin{tabular}{clcc}
\hline No. & Mother's Education & Frequency & Percentage \\
\hline 1. & Illiterate & 56 & 93.33 \\
2. & Quran Majeed & 04 & 06.67 \\
\hline Total & ---- & 60 & 100.00 \\
\hline
\end{tabular}

From the information given in Tables-3 and 4, it is clear that most of the parents of female child labour are illiterate. From among 60 fathers of the female child workers, 51 fathers are illiterate, which is 85 per cent of the total. Eight of the fathers of female child workers cleared primary school. The father of only one female child worker had done his matriculation. As far as mother's education is concerned, 94 per cent of the total surveyed females' mothers were illiterate and the remaining were those who could just recite the Holy Quran. Parents' education determine the child's education. Most of the surveyed female children were found to be either completely illiterate or nominally educated. These children started working at an early age and could not find an opportunity to attend school. Information about the ages of the female child worker at the time of their first employment and about their education is presented in Tables-5 and 6. 
Table-5: Distribution of Female Child Labour According to Starting Age of Work.

\begin{tabular}{cccc}
\hline No. & Starting work age (years) & Frequency & Percentage \\
\hline 1. & 04 & 03 & 05.00 \\
2. & 05 & 12 & 20.00 \\
3. & 06 & 12 & 20.00 \\
4. & 07 & 08 & 13.34 \\
5. & 08 & 10 & 16.67 \\
6. & 09 & 05 & 08.34 \\
7. & 10 & 06 & 10.00 \\
8. & 11 & 02 & 03.34 \\
9. & 12 & 02 & 03.34 \\
\hline Total & ---- & 60 & 100.00 \\
\hline
\end{tabular}

Table-6: Distribution of Female Child Labour According to Their Educational level

\begin{tabular}{clcc}
\hline No. & Educational level & Frequency & Percentage \\
\hline 1. & Illiterate & 32 & 53.34 \\
2. & Reciting Quran & 11 & 18.34 \\
3. & Completed Quran & 02 & 03.34 \\
4. & Primary & 08 & 13.34 \\
5. & Quran + Primary & 07 & 11.67 \\
\hline Total & ---- & 60 & 100.00 \\
\hline
\end{tabular}

Most of the surveyed female child labour started working at a very early age. About 75 per cent of the total surveyed female children started working between four to eight years. Due to the work load at this early age, they were unable to attend school or learn any skill. The majority of them were found illiterate. Table- 6 shows that female child labourers who were illiterate were 32 out of 60 , which was 53.34 per cent of the total. Those who could just recite the Quran were about 22 per cent. Their being illiterate and unskilled makes them vulnerable and turns them into helpless beings very easy to be targeted and preyed upon throughout their lives. After them their children must suffer the same fate and thus a vicious circle of child labour persists. That is why family tradition is another major determinant of female child labour. The fathers of most of the surveyed female children were working in blue-collar jobs, their mothers had either worked as child labour or were still doing such work. Information about the mother's job is given in Table-7. 
72 The Lahore Journal of Economics, Vol.4, No.1

Table-7: Distribution of Female Child Labour According to the Job of the Mother

\begin{tabular}{clcc}
\hline No. & \multicolumn{1}{c}{ Mother's Job } & Frequency & Percentage \\
\hline 1. & Cleaning + washing & 22 & 36.67 \\
2. & House wife & 28 & 46.67 \\
3. & Farming & 05 & 08.34 \\
4. & Seasonal worker & 02 & 03.34 \\
5. & Weaving carpets & 02 & 03.34 \\
6. & Mid wife & 01 & 01.67 \\
\hline Total & ---- & 60 & 100.00 \\
\hline
\end{tabular}

Large family size is considered another major cause of child labour. Most poor families have 5 to 6 children on average. The incomes of these families are too low to fulfill even such basic needs as food and clothing. As a consequence, elder children have to share the burden of living. Innocent little hands serve others or weave carpets instead of studying or playing. Surveyed data about the number of sisters and brothers is given in Tables-8 and 9.

Table-8: Distribution of Female Child Labour According to the Number of Sisters

\begin{tabular}{clcc}
\hline No. & \multicolumn{1}{c}{ No. of sisters } & Frequency & Percentage \\
\hline 1. & One sister & 08 & 13.34 \\
2. & Two sisters & 09 & 15.00 \\
3. & Three sisters & 10 & 16.67 \\
4. & Four sisters & 07 & 11.67 \\
5. & Five sisters & 06 & 10.00 \\
6. & Six sisters & 06 & 10.00 \\
7. & Seven sisters & 03 & 05.00 \\
8. & Eight sisters & 04 & 06.67 \\
9. & Nine sisters & -- & -- \\
10. & Ten sisters & 03 & 05.00 \\
11. & Eleven sisters & 01 & 01.67 \\
12. & No sisters & 03 & 05.00 \\
\hline Total & ---- & 60 & 100.00 \\
\hline
\end{tabular}


From Tables- 8 and 9, it is clear that most of female child labourers belong to large size families. About 65 per cent female child labourers have sisters of ages ranging from 2 to 6 years (Table-8) and about 75 per cent have two to five brothers.

Table-9: Distribution of Female Child Labour According to the Number of Brothers

\begin{tabular}{clcc}
\hline No. & No. of Brothers & Frequency & Percentage \\
\hline 1. & One brother & 12 & 20.00 \\
2. & Two brothers & 20 & 33.34 \\
3. & Three brothers & 15 & 25.00 \\
4. & Four brothers & 05 & 08.34 \\
5. & Five brothers & 05 & 08.34 \\
6. & No brothers & 03 & 05.00 \\
\hline Total & ---- & 60 & 100.00 \\
\hline
\end{tabular}

Most of the surveyed female child labourers were those who either do not have any or have only one working brother. Table-10 gives the information about the number of brothers of surveyed female child labour, who work.

Table-10: Distribution of Female Child Labour According to the Number of Working Brothers

\begin{tabular}{clcc}
\hline No. & No. of working brothers & Frequency & Percentage \\
\hline 1. & One brother & 13 & 21.67 \\
2. & Two brothers & 08 & 13.34 \\
3. & Three brothers & 05 & 08.34 \\
4. & Four brothers & 02 & 03.34 \\
5. & No brother & 32 & 53.34 \\
\hline Total & ---- & 60 & 100.00 \\
\hline
\end{tabular}

It is clear that about 75 per cent of the surveyed female child labourers either do not have any or only one working brother.

With the increase in the number of brothers who work, the number of female working children decreases. One of the major causes of female child labour, as of the male child labour, is the rapid increase in wage rates 
of adults and comparatively very normal wages paid to children for the same work. Generally, the daily wages of a child range from Rs. 10/- to Rs. 60/-. The weekly income ranges from Rs. 50/- to Rs. 130/-. The monthly income of a child ranges from Rs. 100/- to Rs. 800/- (Sabeeha; 1979). Findings about the monthly income of female child labour are presented in Table-11. The majority of the working female children were paid upto Rs. 300/- per month for 6 to 12 hours work per day. Twenty three per cent children work long hours doing all types of odd jobs with the promise that they will be paid at the time of marriage in the form of a dowry. This is actually a very shrewd and callous tactic to avoid payment. Employing female child labour on the promise of paying them in the form of a dowry, the scheming employers try their best to delay marriage for as long as possible even for those girls who wish to get married. The health of these working children were found unsatisfactory as they had only one or two holidays per month, worked long hours in unhygienic conditions and suffered from malnutrition. Another hypothesis tested in the study is that educated and rich people who publicly raise slogans against child labour, are the major

Table-11: Distribution of Female Child Labour According to Monthly Payments

\begin{tabular}{clcc}
\hline No. & Education & Rs. Per month Frequency & Percentage \\
\hline 1. & 100 & 05 & 08.34 \\
2. & 150 & 02 & 03.34 \\
3. & 200 & 16 & 26.67 \\
4. & 250 & 02 & 03.34 \\
5. & 300 & 10 & 16.67 \\
6. & 350 & 01 & 01.67 \\
7. & 400 & 03 & 05.00 \\
8. & 500 & 04 & 06.67 \\
9. & Dowry & 14 & 23.34 \\
10. & Rs. 200 for dowry & 03 & 05.00 \\
\hline Total & ---- & 60 & 100.00 \\
\hline
\end{tabular}

employers of female as well as of male child labour. They habitually exploit child labour, paying the children very low wages. Information about this is presented in Table-12. Most employers of these surveyed female working children are educated and well off people. Although these employers themselves include highly paid salaried people, successful businessmen, traders etc. they pay the children very low wages. The survey shows that 
about 32 per cent of the employers are arts or science graduates, about 34 per cent hold master's degrees or some equivalent professional degree. About 70 per cent of the female child labour were employed by businessmen and landlords and the remaining were employed by doctors, engineers, professors, etc.

Table-12: Distribution of Female Child Labour According to Education of Head of the Family where she is working

\begin{tabular}{clcc}
\hline No. & \multicolumn{1}{c}{ Education } & Frequency & Percentage \\
\hline 1. & Matric & 08 & 13.33 \\
2. & F.A., F.Sc. & 13 & 21.67 \\
3. & B.A., B.Sc. & 19 & 31.67 \\
4. & M.A., M.Sc. & 07 & 11.67 \\
5. & M.B.A. & 01 & 01.67 \\
6. & B.Sc. Engineering & 01 & 01.67 \\
7. & M.B.B.S. & 09 & 15.00 \\
8. & D.H.M.S. & 02 & 03.34 \\
\hline Tota1 & ---- & 60 & 100.00 \\
\hline
\end{tabular}

Table-13: Distribution of Female Child Labour According to Education of Head of the Household where she is working

\begin{tabular}{clcc}
\hline No. & Occupation & Frequency & Percentage \\
\hline 1. & Landlord & 19 & 31.67 \\
2. & Businessmen & 22 & 36.67 \\
3. & Doctor & 09 & 15.00 \\
4. & Engineer & 02 & 03.34 \\
5. & Bank Officer & 01 & 01.67 \\
6. & Govt. Service & 02 & 03.34 \\
7. & Professor & 03 & 05.00 \\
8. & Homeo Doctor & 02 & 03.34 \\
\hline Total & ---- & 60 & 100.00 \\
\hline
\end{tabular}




\section{Conclusion and Policy Implications}

As has already been stated, child labour has become a serious problem. There is a great hue and cry in developed countries against child labour in developing countries. Children are not allowed by law to work. But despite this, widespread child labour is a fact of life in the developed and developing countries. The reason for increasing child labour is that it is not as simple a phenomenon as it appears to be and requires a comprehensive consideration of family as well as of socio-economic conditions in developing countries, which are the causes behind ever increasing child labour. The analysis made in this paper suggests and discusses the major causes of female as well as male child labour. It is the unbearable economic pressure exerted on the parents that makes them push their children to work. The children have no choice except to submit to their parents' authority. They are compelled to share the economic burden of their large families.

Education is the best antidote against child labour. But both parents and children must be convinced that education can solve their problems and is to their advantage. Firstly, governments and international institutions such as the ILO should take effective measures to provide free education and training to these working children. Free and easy access to education may have an effective impact in reducing child labour. There is a very strong bias against female children becoming educated in vocational training as it is regarded as some unheard of abomination. Such attitudes must be tackled head on and eliminated. With the addition of another child at regular intervals, the elder children are burdened with added workload and new responsibilities.

The child labour problem needs to be considered as a part of manpower planning. There should be compromises concerning the application of the child labour prohibition law. Child labour must be prohibited in certain industries where the atmosphere and conditions are inimical to children and should be amended and made adequately flexible to allow the children to work in certain fields in a poverty-ridden society such as Pakistan. The exploitation of child labour should be curbed. For an equitable and adequate implementation of labour laws in poor developing countries such as Pakistan, a group of social volunteers comprising workers, employers, government officers, media experts, members of non-government organisations and educationists, etc., should make earnest and sincere efforts to achieve the objective of minimising the miseries of child labour in order to improve the children's quality of life as much as possible. 


\section{References}

Akbar, Mansoor: 'Tragedy of Child Labour in Pakistan', The Daily, Pakistan Times, Lahore, February 12, 1994.

Ali, Karamat, 1984. Political Economy of Rural Development, Lahore, Vanguard Books.

Ali, Karamat: 'Mazdoor Bachay Aik Muashi Masilah Jo Kai Masail Ko Janm Dhey Raba Hay', Khabar Nama: Pakistan Teacher's Forum, (11:2) Multan, 1994.

Anwar, M. and M. Naeem: 'Situation of Children in Rural Punjab', Department of Sociology, University of the Punjab, Lahore, 1986.

Awan, A. Saeed and Abid Ali Khan: 'Child Labour in Carpet Weaving Industry in Punjab', UNICEF, Punjab in Collaboration with Centre for the Improvement of Working Conditions and Environment, Lahore, 1992.

BBC, World News, Telecast on April 1, 1994 at 13.25 hours GMT.

Blundell, R; and J. Ham and C. Meghir. 'Unemployment and Female Labour Supply', Conference Papers, Supplement to Economic Journal, Vol. 97, Oxford and New York, 1986.

Cheema, M. Asghar, Saif-ur-Rehman and Nosheen Gu1: 'Economic Value of Children in Rural Area of Pakistan, A Case of Faisalabad', Economic Review: Vol. XXIV, No.4, 1993.

Convention on the Rights of the Children, Islamabad UNICEF Publication, printed at Pictorial Printers Islamabad, 1990.

Child Labour in America, The Daily Dawn Karachi, September 19, 1992.

Dar, Humayon A. 'Legislation against child labour is not an ideal solution', The Daily, The News, October 4, 1996.

'Evil of Child Labour': Editorial The Daily Dawn, Karachi, May 19, 1994.

George, N. 'An Explanatory Study of the Problems of the Child Labour in Carpet Weaving', Master Thesis, Department of Sociology, University of the Punjab, Lahore, 1981.

Hafeez, Sabeeha: 'Some Aspects of Child Labour in Pakistan', Department of Sociology, University of Karachi, 1979. 
Hafeez, Sabeeha: 'The Unprotected Ones', The Herald, Monthly, 1979.

Hafeez, Sabeeha, 1988. The Changing Pakistan Society, Karachi, Royal Book Company.

Hussain Akmal, 1988. Strategic Issues in Pakistan's Economic Policy, Lahore, Progressive Publishers.

Hussain, Akmal: 'Poverty Alleviation Strategy for Pakistan', The Daily Pakistan Times, Lahore, August-September, 1993.

Khan, Shaheen: 'Compelled Child Labour in Punjab', A case study; Lahore, Punjab Economic Research Institute, 1982.

Mergos, J. George: 'The Economic Contribution of Children in Peasant Agriculture and Effect of Education, Evidence from Phillippines', The Pakistan Development Review (31:2) Summer, 1992.

Nichols, Martha: 'Third World Child Labour', The Daily Nation, Lahore, March 3, 1993.

Raja Chand: 'Child Labour, An Explanatory Study of Fifty Children Working in Auto Workshops', Deptt. Of Social Work, University of the Punjab, Lahore, 1983.

'State of World's Children', Islamabad, UNICEF, 1991.

Statistical Pocket Books of Pakistan, 1991: Statistic Division, Government of Pakistan, March, 1991.

The Daily Dawn Karachi, April 22, 1993.

Weiner, M. and Omar Noman: The Child and the State in India and Pakistan, Oxford University Press, Pakistan, 1994.

'Why Do Children Work?' Young World, The Daily Dawn Karachi, June 30, 1994.

'Without Child Labour', The Daily Dawn Karachi, June, 1990.

Yotopoulos, P.A. and Y. Kuroda: 'A Subjective Equilibrium Approach to the Value of Children in Agricultural Household', The Pakistan Development Review 27:3, 1988. 